friends to secure his release in 1876 , but he continued his medical, scientific and humanitarian work in east Siberia. Here he bought horses and reindeer for starving natives and introduced rabbit and goatbreeding into Kamchatka to give the native population a surer livelihood. The last years of his life brought him many honours from his native Poland, for he lived until 1931, dying in his ninety-ninth year. His earnest wish for good relations between the Slav peoples was not realized in his life-time, but his work in this connexion may inspire others to work for the same ideal now that there is close collaboration between Poland, the U.S.S.R. and Czechoslovakia in the many common aims that link them with other lands in the struggle for liberty.

\section{Infant Protection in Mexico}

IN an article on this subject in the May issue of the Boletin de la Oficina Sanitaria Panamericana, Dr. Salvador Zubirán, Under-Secretary of Public Assistance, states that Mexico is trying to reduce its high infant mortality, which was 30.5 per 1,000 births in 1905 and $122 \cdot 7$ in 1939 , by the establishment of child welfare centres which were opened in 1929. In 1937 they were placed under a single Government department, and child welfare became a social as well as a medical obligation of the Government, and lost its 'charity' implications. Important objectives include the integration of the home, establishment of foster homes for deserted children, adoption of orphans, pre-natal training for the mother, vocational training for her if she has to work, and aid from pregnancy until the child is six years old. A children's hospital is being opened in Mexico this year to serve as a centre for medico-social education, scientific investigation and the spread of pædiatric information.

\section{Anthropology in Switzerland}

THE Bulletin der Schweizerischen Gesellschaft für Anthropologie und Ethnologie, 1941-42, contains a list of members of the Society, a report of meetings held during 1941, and three original articles. Dr. Hans Dietschy advances a number of theories to account for and to explain the attributes and nature of the Aztec pantheon. Dr. Lucia Graf describes some late medieval skeletal remains which were excavated from Holderbank in the Solothurn Canton in 1940, and Prof. Otto Schlaginhaufen provides a very complete anatomical and anthropometric description of four skeletons from Darvela near Truns. Late Iron Age (la Tène period) material was found with these bones. The cranial indexes of the skulls were respectively $76 \cdot 1$ and $74 \cdot 5$ for two male specimens, and $79 \cdot 4$ and $82 \cdot 8$ for two female skulls.

\section{Committee on Synthetic Rubber}

Srr Andrew Duncan announced in the House of Commons on July 22 the formation of a Committee to consider the question of synthetic rubber to be constituted as follows: Mr. F. W. Bain, chairman of the Chemical Control Board of the Ministry of Supply (chairman); Sir Edward V. Appleton, secretary of the Department of Scientific and Industrial Research; Dr. J. W. Armit, director-general of explosives at the Ministry of Supply ; Sir Robert Robinson, Waynflete professor of chemistry in the University of Oxford ; and Dr. F. Roffey, controller of chemical research at the Ministry of Supply.

\section{Earthquake Registered at Kew}

ON July 12, a strong earthquake was registered on the seismographs at Kew Observatory. It began recording with iP compressional on all three components at $05 \mathrm{~h} .17 \mathrm{~m}$. $47 \mathrm{~s}$. U.T. From a tentative interpretation, the $e S$ wave registered on all three components (north-south, east-west and vertical) at 05h. $28 \mathrm{~m}$. 09s. U.T., which gives the epicentral distance according to the tables in use at Kew as $9,230 \mathrm{~km}$. A full suite of pulses was registered, the maximum ground movement at Kew being $29 \mu$ amplitude at $05 \mathrm{~h}$. $53 \mathrm{~m}$. $15 \mathrm{~s}$. U.T. on the vertical component. The earthquake finished recording at 09h. 05m. U.T.

\section{Announcements}

Lord Louis Mountbatten, who is a vice-president of the Institution of Radio Engineers, has given a prize to the Institution, to be known as the Mountbatten Medal ; it will be "awarded to the candidate who has proved himself the best candidate amongst those of the Royal Navy or Air Force who have presented themselves for the Graduateship Examinations of the Institution held during the year".

The British Museum (Natural History), Cromwell Road, South Kensington, London, will re-open to the public on August 1. Owing to shortage of staff and the evacuation of many exhibits, it is possible to open at present only very few of the galleries. The times of opening will be $10-4$ on weekdays and 2-4 on Sundays. Small children must be accompanied by an adult or a responsible older child.

THE trustees of the Leverhulme Research Fellowships have approved the following awards for research, tenable for varying periods up to two years: Dr. M. R. Anand, for work on landmarks in Urdu literature; Dr. R. S. Bagnall, for a monograph of the British Apterygota, including springtails, bristletails, and other primitive groups; Miss A. M. Cameron, warden, Lady Margaret Hall Settlement, Lambeth, for the study of voluntary social service by wage earners.

Writring with reference to the review entitled "A Fateful Legacy" in NATURE of July 18, p. 72, Prof. Macgregor Skene points out that the complete quotation from Darwin's "Origin of Species", and indeed the last sentence of the book, is: "There is grandeur in this view of life, with its several powers, having been originally breathed by the Creator into a few forms or into one; and that, whilst this planet has gone eycling on according to the fixed law of gravity, from so simple a beginning endless forms most beautiful and most wonderful have been, and are being evolved."

ReferRING to the obituary of Sir Daniel Hall in NATURE of July 25 , Mr. G. M. Johnson, head master, states that the school in which Sir Daniel Hall was so long interested, and in which he did such good work as chairman of the governors, is The Lord Wandsworth College, Long Sutton, Basingstoke, Hants, and not as stated in the obituary notice, at Wantage. Sir Daniel Hall was taking an active part in the life of the College until he entered the nursing home in London, some three weeks before his death. 